\section{Bioactivity and potential therapeutic benefits of some medicinal plants from the Caatinga (semi-arid) vegetation of Northeast Brazil: a review of the literature}

\author{
Maria I. G. Silva, Carla T. V. de Melo, Leonardo F. Vasconcelos, \\ Alyne M. R. de Carvalho, Francisca C. F. Sousa*
}

Departamento de Fisiologia e Farmacologia, Faculdade de Medicina, Universidade Federal do Ceará, Brazil.

\begin{abstract}
Medicinal plants have been used in traditional medicine for several thousand years all over the world. In this sense, information from Brazilian ethnic groups on folk medicine have contributed to the discovery of pharmacological activities from various plant-derived agents potentially leading to the innovative drugs. The Caatinga (semi-arid) vegetation is a highly threatened biome, covering a vast area in northeastern Brazil and has suffered from strong human influence for many decades. Many plants species found in the Caatinga have been widely used in folk medicine and for commercial manufacturing of phytotherapeutic products. Thus, the present review aims to disseminate to the scientific community some known species of medicinal plants found in the Caatinga that have been studied and analyzed in pharmacological scientific assays. Among the species that stood out for their local importance and multiplicity of uses were: Amburana cearensis (umburana-de-cheiro), Anadenanthera colubrina (Vell.) Brenan (angico-branco), Anacardium occidentalis L. (cajueiro), Bauhinia forficata Link (mororó), Cissus sicyoides L. (insulina-vegetal), Myracrodruon urundeuva Allemão (aroeira-dosertão) and Zingiber officinalis L. (gengibre). The present study shows that several herbal constituents from Caatinga plants, whose pharmacological actions have been well characterized, may be relevant candidates for future and innovative therapeutic development.
\end{abstract}

Revista Brasileira de Farmacognosia Brazilian Journal of Pharmacognosy 22(1): 193-207, Jan./Feb. 2012

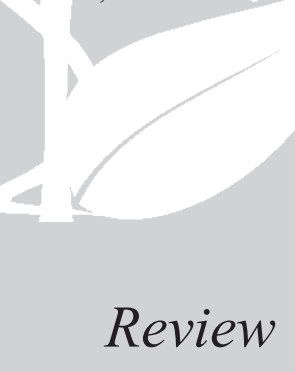

Received 14 Mar 2011

Accepted 22 Jun 2011

Available online 16 Sep 2011

Keywords: caatinga

medicinal plants potential therapeutic pharmacological assays

ISSN 0102-695X http://dx.doi.org/10.1590/S0102$695 \mathrm{X} 2011005000171$

\section{Introduction}

Medicinal plants have been used in many cultures for thousands of years and information on the use of natural resources has played a vital role in the discovery of novel products from plants as chemotherapeutic agents. Brazil not only has one of the world's highest levels of biodiversity but also it has a wealth of traditional knowledge accumulated by local people who have direct access to nature and to the products of biodiversity (Albuquerque et al., 2007). In this sense, information from Brazilian ethnic groups on traditional medicine have contributed to the discovery of pharmacological activities from several plant-derived agents, which have resulted in a significant body of publications (Almeida et al., 2001; Sousa et al, 2004a; 2005; De Sousa et al., 2006; Amaral et al., 2007; Silva et al., 2007; Volpato et al., 2008; Silva et al., 2009a; Silva et al. 2009b; Morais at al., 2010). In spite of this, the current knowledge on the biodiversity of ecosystems as, for example, of the northeast region, is still very embryonic.
The Caatinga (semi-arid) vegetation is a highly threatened biome, covering a vast area in northeastern Brazil. The ecosystem of the Caatinga occupies an area of approximately $750000 \mathrm{~km}^{2}$, accounting for about $10 \%$ of the Brazilian territory and approximately $60 \%$ of the northeast region, including parts of the states of Piauí, Ceará, Rio Grande do Norte, Paraíba, Pernambuco, Alagoas, Sergipe, Bahia, and Minas Gerais (Silva \& Albuquerque, 2005). This biome is dominated by one of the few types of vegetation whose distribution is totally restricted to Brazil (Hueck 1972; Ferri 1980) and has suffered from strong human influence for many decades, resulting in the conversion of extensive areas to pasture or farm land and the intensive harvesting of wood products, especially as energy sources (Albuquerque \& Andrade, 2002; Albuquerque et al., 2005).

Despite the fauna and flora are becoming greatly altered, many plants species from the Caatinga are widely known and used in folk medicine and for commercial manufacturing of phytotherapeutic products 
(Albuquerque et al., 2007), although detailed studies are still needed concerning these botanical resources and the impact that intensive use might have on their availability. In this sense, the number of studies on medicinal plants from the semi-arid region of northeast Brazil has grown progressively, most of them focusing on listing plants together with their folk therapeutic indications, manner of use, and the plant parts used (Cabral \& Agra, 1998; Costa-Neto \& Oliveira, 2000; Almeida \& Albuquerque, 2002; Almeida et al., 2006).

The present work focused on analyzing published information that intends to contribute to the identification of Caatinga resources with potential medicinal applications. Therefore, this study aims to evidence the local diversity of medicinal plants of Caatinga and disseminate to the scientific community some species that have been studied and analyzed in scientific assays highlighting species that deserve further study.

\section{Database collection}

The studies included in this review were identified primarily by using computerized literature searches of the PubMed and Lilacs databases. The selected papers (about 106) were published between 1980 and 2010. The identity of each plant was carefully checked based on the description given in the works. Only those plants whose extracts and/or isolated constituents showed clear pharmacological effects in animal models or isolated organs were included in this review.

\section{Revised medicinal species from the Caatinga region}

Concerning medicinal plants, there are few studies that enable a wider vision of the great diversity of species used by the Caatinga population for therapeutic purposes. Much of the traditional knowledge about plants, especially medicinal plants, is being lost with time, either because of the lack of studies or by the inadequate use of plant resources (Silva \& Albuquerque, 2005). On the other hand, some studies show the interest of researchers on the therapeutic effects of several medicinal plants found in Caatinga. In this sense, a short list of the species covered in this work includes: Amburana cearensis (cumaru), Anadenanthera colubrina (Vell.) Brenan (angico-branco), Anacardium occidentalis L. (cajueiro), Bauhinia forficata Link (mororó), Cissus sicyoides (insulina-vegetal), Myracrodruon urundeuva Allemão (aroeira-do-sertão) and Zingiber officinalis L. (gengibre).

\section{Amburana cearensis (Allemao) A.C. Sm., Fabaceae (umburana-de-cheiro)}

Amburana cearensis A. C. Smith (syn. Torresea cearensis Fr. All.), Fabaceae, is a tree from Ceará State, popularly known as 'cumaru', 'amburana' or 'amburanade-cheiro' in northeast Brazil. Its trunk bark and seeds have been traditionally used as an antispasmodic, antiinflammatory, antitussive, and mainly for the treatment of asthma (Braga, 1976; Correa, 1984). From the trunk bark of $A$. cearensis several compounds were isolated, including protocatechuic acid, coumarin, flavonoids (isokaempferide-IKPF, kaempferol, afrormosin and 4'methoxyfisetin) and the phenol glucosides, amburosides A and B (Canuto \& Silveira, 2006; Bravo \& Sauvain, 1999).

Isokaempferide (or IKPF), the main flavonoid of the trunk bark of A. cearensis, also isolated from other plant species (Saeidnia et al., 2005), presented antibacterial activity for $C$. cucumerinum and B. cerus in earlier study (Wang et al., 1989), as well as antiviral activity against type 1 poliovirus and type 15 rinovirus (De Meyer et al. , 1991). These studies corroborate, at least in part, the traditional use of $A$. cearensis in infectious respiratory diseases. Subsequently (Banskota et al., 2000), IKPF was shown to inhibit the TNF-alphainduced cell death and the growth of tumor cell lines (Costa-Lotufo et al., 2003). Furthermore, this compound was recently found to present anti-inflammatory activity in rats and mice by researchers from our laboratory (Leal et al., 2009).

Leal et al. (2003) also demonstrated that hydroalcoholic extract (HAE), coumarin (Coum) and flavonoid fraction (FF) isolated from the trunk barks of A. cearensis have anti-inflammatory and smooth muscle relaxant activities. They inhibited both leucocyte and neutrophil accumulation in the carrageenan or $N$-formylmethyl-leucyl-phenylalanine (fMLP)-induced migration in rat peritoneal cavity, and histamine- and serotonin induced increases of cutaneous vascular permeability. In the guinea-pig trachea pre-contracted with carbachol and histamine, the HAE, Coum and FF evoked relaxation in the presence of the three agonists, as well as inhibited the histamine and serotonin-induced increase of cutaneous vascular permeability. HAE and Coum also caused significant relaxation of the rat vas deferens previously contracted with adrenaline, acetylcholine or barium chloride. Results from this study suggest antiinflammatory and bronchodilator effects of HAE, Coum and FF, justifying also the traditional uses of $A$. cearensis as anti-inflammatory and bronchodilator in the treatment of respiratory tract diseases. In addition, antinociceptive effect of the ethanolic extract was recently showed (Oliveira et al., 2009).

The literature presents some information of pharmacological studies on glucoside amburosides A, however, reports about amburosides B are scarce. Leal et al. (2005) evaluated the potential neuroprotective 
properties of amburoside A on rat mesencephalic cell cultures exposure to the neurotoxin 6-hydroxydopamine (6-OHDA). The study showed that the glucoside tested, acting as an antioxidant compound, presented a significant neuroprotective effect, suggesting that this compound could provide benefits as a therapeutic agent in neurodegenerative disease such as Parkinson's. The antiinflammatory activity of amburoside A was also showed (Leal et al., 2009) and seems to be related to an inhibition of inflammatory mediators, such as TNF- $\alpha$, histamine, serotonin, prostaglandin E2, and leucocytes infiltration.

In addition, hepatoprotective effect from amburoside A was also demonstrated by Leal et al. (2008). Acute treatments of carbon tetrachloride (CCl4) intoxicated rats significantly inhibited the increase in serum aspartate aminotransferase (AST) and alanine aminotransferase (ALT) levels. In hepatic tissues, it inhibited $\mathrm{CCl}_{4}$-induced thiobarbituric acid-reactive substances formation, indicating a blockade of $\mathrm{CCl}_{4}^{-}$ induced lipid peroxidation, as well as reversed the decrement in glutathione contents and restored catalase activity to normal values. The cited study related the protective effect of amburosides A to the phenolic nature of this glucoside and suggests further hepatoprotective potential from $A$. cearensis species.

\section{Anadenanthera colubrina (Vell.) Brenan, Fabaceae (angico-branco)}

The leguminous tree Anadenanthera colubrina (Vell.) Brenan, known in northeastern Brazil as "angico" or "angico-branco", belongs to the family Fabaceae and is widely distributed in the Caatinga. It has been used in traditional medicine to treat respiratory problems and inflammations (Delgobo et al., 1998; Maia, 2004). The seeds of Anadenanthera peregrine (L.) Speng., a related species, are used to prepare yоро, a hallucinogenic inhalant used by the "curandeiros" (healers) of the Piaroa tribe inhabiting southeastern Venezuela (Rodd, 2002).

In the last few decades, studies undertaken on polysaccharides isolated from natural sources have received considerable attention for their potential role as 'biological response modifiers', in terms of immunomodulatory and anti-tumor effects (Han et al., 1999; Ooi \& Liu, 2000). The A. colubrina is a complex branched high-arabinose heteropolysaccharide that forms an aqueous solution of low viscosity (Delgobo et al., 1998). In this sense, the immunomodulatory and anti-tumoral effects of an acidic heteropolysaccharide containing mainly galactose and arabinose (ARAGAL), isolated from the gum of the A. colubrina were previously studied (Moretão et al., 2003; 2004). ARAGAL presented effects on the immune system of mice, increasing the percentage of activated macrophages in vitro and in vivo, anion superoxide production by macrophages from ARAGAL-treated mice, and phagocytic activity (Moretão et al., 2003). Subsequently, the same authors (Moretão et al., 2004) showed that mice treated with ARAGAL increased peritoneal exudate cell (PEC) numbers, increased TNF- $\alpha$ production by peritoneal macrophages, as well as showed anti-tumoral activity against Sarcoma 180 cells in ascites or solid tumors. The results from this study suggest a possible role as a 'biological response modifier' for ARAGAL.

Several natural products have been discovered to inhibit Lipoxygenase (LO), including some flavonoids agents (You et al., 1999a; 1999b; Sadik et al., 2003). Inhibition of LO is a significant area of research due to its implication in cancer, atherosclerosis and a variety of inflammatory diseases (Steele et al., 1999; Brash, 1999). In this context, Gutierrez-Lugo et al. (2004) described the isolation and characterization of the flavonoid anadanthoflavone, together with other known compounds (alnusenol, lupenone, lupeol, betulinic acid, $\alpha$-amyrin, $\beta$-amyrin, $\beta$-sitosterol, stigmasterol, apigenin, 4-hydroxybenzoic acid and cinnamic acid) from the aerial parts of $A$. colubrina, as well as their effects on human and soybean LO. Results from this report showed that anadanthoflavone was found to be active against platelet 12-lipoxygenase and human reticulocyte 15-lipoxygenase; apigenin selectively inhibited the activity of reticulocyte 15-lipoxygenase, while lupenone, lupeol and $\alpha$-amyrin were found active against soybean lipoxygenase. These results may have implications with respect to possible protective effects in cancer, atherosclerosis and inflammatory diseases from some compounds of Anadenanthera colubrina, justifying its use in traditional medicine at least to treat inflammations problems.

\section{Anacardium occidentale L., Anacardiaceae (cajueiro)}

Anacardium occidentale L. (cashew), member of the family Anacardiaceae and presently cultivated in many regions of the world, is a tropical tree originally indigenous to Brazil, where is popularly known as "caju". The tree yields the so-called cashew apple to which the nut is attached (Barros, 1993; Konan \& Bacchi, 2007; Morais et al., 2010). Although Brazil is the major exporter of cashew nut, the cashew tree is the source of many useful products, including the pseudo-fruit (cashew apple) that is used to make juices and wines (Aguiar et al., 2001). Also, the fruits, stem bark and leaves extracts have been traditionally used for the treatment of mouth and peptic ulcers, intestinal disturbances, dyspepsia, asthma, diabetes, sore throat, asthma, bronchitis and inflammatory diseases (Correia, 1984; Lorenzi \& Matos, 2002; Luiz-Ferreira et al., 2008), as well as in treatment 
of leishmanial ulcers due to Leishmania (Viannia) braziliensis (Franca et al., 1996).

The strongly vesicant cashew nut-shell liquid (CNSL) presents a high amount of anacardic acids, which are also presents in the nut and fruit juice (Toyomizu et al., 2000). Biological and pharmacological investigations carried out on these anacardic acids revealed numerous interesting activities such as parasiticidal (Cui et al, 2008; Pereira et al., 2008), anti-staphylococcus aureus (Kubo et al., 2003), anti-Helicobacter pylori (Castillo-Juárez et al., 2007), antioxidant (Trevisan et al., 2006), lipoxygenase inhibition (Kubo et al., 2008) and inhibition of NF-KB (Nuclear Factor kappa B) (Sung et al., 2008).

De Lima et al. (2008) investigated whether immature cashew nut-shell liquid (iCNSL) has also antioxidant properties and measured the inhibitory activity of acetylcholinesterase (AChE). Results from this study supported a role for iCNSL in providing strong cellular antioxidant protection against hydrogen peroxide and inhibition of AChE activity. Such properties can be related to the chemical constituents of iCNSL, including anacardic acids, cardol and cardanol. Thus, it is thought that iCNSL could be pathologically important in various neurodegenerative processes, including cognitive deficits that occur during normal cerebral aging, Alzheimer's and Parkinson's disease. Also, this natural antioxidant could be better utilized in functional food formulations and may represent a cheap source of cancer chemopreventive agents. Recently, the anacardic acids from $A$. occidentale were also studied for their gastroprotective activities using the ethanol-induced gastric damage in mice as the test model (Morais et al., 2010). Results from this study suggest that these constituents afford gastroprotection principally through an antioxidant mechanism, as well as by stimulation of endogenous prostaglandins and nitric oxide, and opening of $\mathrm{K}^{+}$ATP channels.

Besides the nut of the A. occidentale, also the cashew apple juice has been reported to show several pharmacological properties such as anti-tumor (Kubo et al., 1993), antimicrobial (Kozubek et al., 2001), admirable antioxidant potential and antimutagenic properties (MeloCavalcante et al., 2003, 2005; Trevisan et al., 2006). Antiulcerogenic effect was also showed from plant leaf hydroethanolic extract (Konan \& Bacchi, 2007), while leaf aqueous extract was demonstrated to protect against streptozotocin-induced diabetes in rats (Kamtchouing et al., 1998). Also, the stem bark is astringent and rich in tannins, which possibly supports its popular use in healing. In fact, earlier, tannins isolated from the bark of the plant were demonstrated to possess anti-inflammatory effects in some models of inflammation (Mota et al., 1985). Subsequently, this activity was described in two different models of inflammation, having reduced paw edema induced by fresh egg albumin in rats (Ojewole, 2004) and inhibited skin dye leakage in mice after subcutaneous injection of LPS (Olajide et al., 2004). More specifically, the anti-inflammatory and cicatrizing effects from the aqueous extract of $A$. occidentale were shown by the clinical evaluation of patients with skin injury or mucosa lesions such as oral or vulva erosion, uterus inflammation and body ulceration (Lopes et al., 2003). Several further investigations were carried out to determine possible mechanisms involved in antiinflammatory properties from $A$. occidentale (Olajide et al., 2004; Vanderlinde et al., 2009).

As evidenced in the studies discussed above, several pharmacological properties from different parts of the A. occidentale validate its folkloric use in diverse alternative health practices. However, further potential uses of this plant are still in need of investigation.

\section{Bauhinia forficata Link, Fabaceae (mororó)}

The recognized use and potential of Bauhinia species to act as hypoglycemic agents have received considerable scientific attention in recent years. Aqueous extracts from Bauhinia species leaves, roots and stems, mainly $B$. cheilantha, B. forficata, B. glabra, B. rufescens, $B$. splendens and $B$. ungulata, have been widely used over time in Brazil and in other countries in the treatment of several illness, specially pain processes, infections and diabetes (Pereira et al., 2004; Macedo \& Ferreira, 2004; Morais et al., 2005; Almeida et al., 2006a; Silva et al., 2006).

Leaves of the pantropical genus Bauhinia are popularly known in Brazil as "pata-de-vaca" (cow's hoof), due to their unique characteristic bilobed aspect (Miyake et al., 1986). Bauhinia divaricata aqueous extract, known in Mexico as "pezunã de vaca", showed a relatively significant hypoglycemic effect in normal mice (Gupta et al., 1980), while the B. megalandra species inhibited the glucose intestinal absorption (Gonzalez-Mujica et al., 2003) in rats. However, the hypoglycemic activity of Bauhinia species has been most extensively researched in B. forficata.

The Bauhinia forficata Link is a member of the Caesalpinioideae subfamily, Fabaceae, commonly found in the Caatinga. The leaves of this species, in the form of aqueous extract, are widely used as an antidiabetic herbal remedy in Brazilian folk medicine (Volpato et al., 2002; Barbosa-Filho et al., 2005; Silva et al, 2006). The first report of Bauhinia forficata hypoglycemic action in diabetic patients was demonstrated by Juliane (1929), and this was confirmed by a further study (Juliane, 1931). Subsequent studies were carried out to determine the constituents responsible for this activity. In this sense, numerous constituents including alkaloids, flavonoids, mucilage, essential oils and tanines were isolated from $B$. forficata (Oliveira \& Saito, 1987).

Flavonoids are a class of natural products of high 
pharmacological potency (Havsteen, 1983) and, among some of the constituents of $B$. forficata, most studies have examined the effects of natural flavonoids in physiological and pathological conditions of glucose metabolism, as well as in lipid peroxidation (Damasceno et al., 2004; De Sousa et al., 2004). Thus, such studies evidenced that $B$. forficata has significant antioxidant activity, beneficial in the prevention of diabetes complications associated with oxidative stress (Khalil et al., 2008).

Some reports have attributed the effects of the $B$. forficata leaf extracts to the main flavonoid derivative (kaempferitrin) (Jorge et al., 2004; De Sousa et al., 2004). In fact, kaempferitrin was found to have an acute lowering effect on blood glucose in diabetic rats and to stimulate the glucose uptake percentile, as efficiently as insulin in muscle from normal rats (Jorge et al., 2004). In recent study, Tzeng et al. (2009) provided evidence of the dual effects of kaempferitrin. It improved insulin resistance by the activation of the classical insulin transduction pathway and increased adiponectin secretion. Taken together, these studies corroborate the potential of glycosylated flavonoid kaempferitrin on the pharmacological properties of B. forficata. Thus, as a result of several scientific investigations, evidences have reinforced the hypoglycemic efficacy of $B$. forficata species and its use as "natural insulin" for the control of diabetes (Miyake et al., 1986; Jorge et al., 2004; Da Cunha et al., 2010), including a study conducted by collaborators from our laboratory (Lino et al., 2004).

On the other hand, in addition to $B$. forficata antidiabetic activity, studies showed further pharmacological properties from this species. For example, an in vitro antitumoral activity was described and related to an unusual nitrogenated compound isolated from the leaves (Lim et al, 2006), while Oliveira et al. (2005) showed that the aqueous extract from aerial parts of $B$. forficata was able to neutralize the clotting activity induced by Bothrops and Crotalus crude venoms. This study concluded that the plant extract is also a promising source of natural inhibitors of serine-proteases involved in blood clotting disturbances induced by snake venoms.

\section{Cissus sicyoides L., Vitaceae (insulina-vegetal)}

Cissus sicyoides L., Vitaceae, a climber plant originally from the Dominican Republic, is commonly found in tropical regions, particularly in Caribbean and Brazil (Cano \& Volpato, 2004). According to previous studies, it has been used in traditional medicine of some countries as a diuretic, anti-inflammatory, antidiabetic and anti-influenza agent (Carvajal et al., 1983; García et al., 2000; Cano \& Volpato, 2004; Bolsoni et al., 2008). In Brazil, C. sicyoides is largely found in Caatinga and used in folk medicine for treatment of several diseases, such as epilepsy, stroke, gastric ulcer, abscesses, as well as it has been used widely as a popular remedy for diabetes mellitus and, for this, is locally known as "insulinavegetal" (insulin plant) or "cipó-pucá" (Dey et al., 2002; Lorenzi \& Matos, 2002; Agra et al., 2007).

In order to validate the popular use of the $C$. sicyoides as an antidiabetic, previous pharmacological studies have been conducted (Mori et al., 2001; Beltrame et al., 2001; Pepato et al., 2003; Viana et al., 2004). Pepato et al. (2003) administered leaf decoctions, over extended periods, to normal and streptozotocin-diabetic rats. Results showed that the treatment significantly reduced the intake of both food and fluid and the volume of urine excreted, as well as the levels of blood glucose, urinary glucose and urinary urea, in comparison with controls. The authors suggested that the $C$. sicyoides mode of action in diabetic does not resemble those of sulphonylurea or insulin but it could act in a similar way to biguanide, via inhibition of gluconeogenesis. Viana et al. (2004) showed that aqueous extract prepared from fresh leaves of the plant significantly decreased blood glucose levels in the model of alloxan-induced diabetes in rats. In addition, considering that triacylglycerides are usually increased in the serum of diabetic patients, while no changes were seen in total cholesterol levels, a significant decrease was observed in plasma triacylglyceride levels of animals. The results from these studies justify the popular use of $C$. sicyoides, pointing out to the potential benefit of the plant aqueous extract in alternative medicine, in the treatment of type 2 diabetes mellitus. Currently, the antidiabetic action of the $C$. sicyoides is in the making of clinical trials (phase II) (Santos et al., 2008) and the results obtained from this study are promising for the future use in medical clinics.

Also, considerable interest has gathered around the role of antioxidants as a means of preventing damage due to the oxidative imbalance found in diabetes (Coppey et al., 2003; Martin-Gallan et al., 2003). In this sense, similar to the observed for B. forficate, Khalil et al. (2008) determined the in vitro antioxidant activity of aqueous extracts from leaves of $C$. sicyoides, suggesting this species as a potential source of natural antioxidants, helpful in the prevention of diabetic complications associated with oxidative stress.

The $C$. sicyoides plant is rich in nutrients and bioactive compounds. The extracts obtained from this species have high contents of amino acids, alkaloids, steroids, terpenes, flavonoids, saponins, tannins, and phenolic compounds, and the fruits are rich in anthocyanins (Toledo et al., 1983; Otshudi et al., 2000). Thus, besides its antidiabetic action, $C$. sicyoides has been furthermore evaluated for its anticonvulsant property in Brazil, where it is also used against epilepsy (Elisabetsky et al., 1988). In fact, in the leaves of this species has been identified the presence of $\alpha$-tocopherol, a compound proved to protect against pentylenotetrazol 
and methylmalonate induced convulsions (Ribeiro et al., 2005) and to prevent the occurrence of epileptic foci in a rat model of posttraumatic epilepsy (Yamamoto et al., 2002). Recently, Almeida et al. (2009) demonstrated the anticonvulsant and also anxiolytic effects of a hydroalcoholic extract obtained from the $C$. sicyoides on mice, probably due to the action of $\alpha$-tocopherol, flavonoid(s) and linalool present in the leaves. Taken together, the cited studies validate the folkloric use of $C$. sicyoides as anticonvulsant.

Furthermore, several additional pharmacological properties have been evidenced from C. sicyoides. A previous study (Beltrame et al., 2002) showed that two compounds isolated from aerial parts of the plant ( $\beta$-sitosterol and sitosterol- $\beta$ D-glucopyranoside) presented antibacterial activity, while the aqueous extract was able to contract isolated guinea-pig aortic rings by increasing the calcium entry through the membrane and mobilizing the internal calcium deposits (García et al., 1997). Aqueous extract was also shown to present cytostatic (Saenz et al., 2000), antinociceptive (Almeida et al. 2006b) and anti-inflammatory (García et al., 2000) effects. In recent study (Ferreira et al., 2008), the methanolic extract obtained from the leaves of $C$. sicyoides was evaluated for the ability to protect the gastric mucosa against injuries caused by different necrotizing agents in rodents. This extract administered by oral route significantly increased gastric volume without exerting antisecretory effect. The effect involved an increase of the defense mechanism of the gastrointestinal mucosa such as oxide nitric and sulfidryl groups that prevent and attenuate the ulcer process. Also, phytochemical evaluation demonstrated the presence of sterol $\beta$-sitosterol (14\%) and quercetin-3-O- $\beta$-D-rhamnoside $(18 \%)$ as the majority constituents in Cissus sicyoides and both constituents have been reported previously as antiulcer activity (Arrieta et al., 2003). These studies corroborate the traditional use of $C$. sicyoides also for the treatment of gastric ulcer.

\section{Zingiber officinale Roscoe, Zingiberaceae (gengibre)}

Zingiber officinale Roscoe, belonging to the family Zingiberaceae, is commonly known as ginger. Originally from Southeast Asia, it was artificially introduced in South America and several countries of the African continent, and is now considered a common constituent of diet worldwide (Chemexcil, 1992; Park \& Pizzuto, 2002). The underground stem or rhizome of this plant has been used as a medicine in Asian, Indian, and Arabic herbal traditions since ancient times (Nadkarni, 1976; Altman \& Marcussen, 2001).

In the traditional medicine of India, Ayurveda, ginger is used extensively to block excessive clotting (in heart diseases), reduce cholesterol and fight arthritis (Sharma \& Clark, 1998), while in traditional Chinese medicine it has been used extensively for more than 2500 years for headaches, colds, as well as is locally considered a pungent and warming (Grant \& Lutz, 2000). In Mediterranean and Western, the plant has been used for the treatment of arthritis, rheumatological conditions and muscular discomfort (Langner et al., 1998; Sharma \& Clark, 1998). In Arabian medicine, ginger is considered an aphrodisiac (Qureshi et al., 1989), while in African is considered to be a mosquito repellent (Duke \& Ayensu, 1985). Also, it has also been suggested for the treatment of various other conditions, including atherosclerosis, migraine headaches, high cholesterol, ulcers, depression, and impotence (Liang, 1992).

In Brazil, the Zingiber officinale plant is known as "gengibre" (ginger). It is widely distributed in the Caatinga and in other regions around the country, where has been consumed as a fresh paste, dried powder, teas, preserved in sugar or in syrup, as well as is commonly found as candy (crystallized ginger). Locally, it has been used mainly as carminative, for indigestion, stomachache, diarrhea, vomit, colds, sorethroat, cough and hoarseness, as well as for the treatment of arthritis and rheumatological conditions besides several other traditional uses. Ginger rhizome is widely commercialized in Brazil due to its use in folk medicine, eating and industry, especially as raw material for manufacture of beverages, perfumes, breads, cakes, cookies and jams (Corrêa Junior et al., 1994; Palharin et al., 2008).

Numerous constituents have been reported to be present in $Z$. officinale, including volatile essential oil, tannins, flavonoids, sulphonatated compounds and pungent principles like zingerone, gingerols and shogaols (Yoshikawa et al., 1993; Ali et al., 2008). In general, flavonoids and tannins (Galvez et al. 1993; Miranda et al., 1993), and recently zingerone (Chen et al., 2007), have been reported to present antidiarrhoeal activity, which has been credited to inhibition of intestinal motility and secretion (Di Carlo et al., 1993) and antimicrobial action (Lutterodt et al., 1999).

Due its spasmolytic actions, the efficacy of ginger against motion or sea sickness was evidenced in several early studies (Grontved et al., 1988; Holtmann et al., 1989; Stewart et al., 1991), as well as it was showed as an antiemetic in nausea and vomiting induced by chemotherapy in a randomized, cross-over and double blind study (Sontakke et al., 2003). In addition to these reports, Geiger (2005) showed that a 5\% solution of essential oil of ginger is an effective post-operative nausea and vomiting prevention when administered preoperatively, concurrently with conventional therapies, to general anaesthesia patients at high risk for postoperative nausea and vomiting, with increased patient satisfaction and less expense to patients and hospital. 
Recently, ginger capsules were effective for decreasing nausea and vomiting during pregnancy (Ozgoli et al., 2009). The authors suggest that a daily total of 1000 $\mathrm{mg}$ of ginger in a capsule preparation can be suggested by care providers as a means of decreasing pregnancy nausea and vomiting in women who tend to herbal medicines. In addition, in isolated guinea pig ileum, several compounds in ginger have been shown to have anti-serotonin (5-hydroxytryptamine) effects (Yamahara et al., 1989; Huang et al., 1991). These early studies suggest that, at least in part, the anti-emetic action of either ginger or some of its constituents may be mediated centrally via 5 -HT3 receptors, as these constituents have small molecular weights and could easily cross the blood brain barrier.

A number of studies shows that some constituents present in ginger may exert cancer preventive effects. The oleo resin from the root of ginger contains [6]-gingerol (the majority pharmacologically active component) and lesser amounts of a structurally related vanilloid, [6]-paradol. Previous studies suggest that both compounds suppress proliferation of human cancer cells through the induction of apoptosis (Lee \& Surh, 1998; Lee et al., 1998) and were found to exert inhibitory actions on the viability of human HL-60 (promyelocytic leukemia) cells (Lee \& Surh, 1998). [6]-Paradol and other structurally related derivatives like [10]-paradol, [3]-, [6]- and [10]-dehydroparadol, induced apoptosis in an oral squamous carcinoma cell line through a caspase-3-dependent mechanism (Keum et al., 2002), while [6]-gingerol was able to inhibit the growth of human colorectal cancer cells (Bode, 2003). It was found that gingerol inhibited the growth of $H$. pylori strains in vitro and this activity may contribute to its chemopreventive effects against colon cancer (Mahady et al., 2003). This anti- H. pylori action was further confirmed by Mahady et al. (2005) and Nostro et al. (2006). Recently, Weng et al. (2010) demonstrated that [6]-shogaol and [6]-gingerol exerted anti-invasive activity against human hepatocarcinoma cells.

Since tumor promotion is closely linked to inflammation and oxidative stress (Fang et al., 2009), many herbs and spices are known to possess antioxidant and anti-inflammatory properties that are believed to contribute to their anticarcinogenic and antimutagenic activities (Chung et al., 2001; Wang et al., 2007). In fact, gingerol, shogaol, paradol and other structurally related substances in ginger were found also to possess considerable antiinflamatory activity (Flynn et al., 1986; Kiuchi et al., 1982; 1992; Nurtjahja-Tjendraputra et al., 2003), while more than fifty antioxidants (mainly [6]-gingerol) isolated from the rhizomes were showed (Aeschbach et al., 1994; Chung et al., 2001; Masuda et al., 2004).

The antiinflammatory-like substances from ginger were found to inhibit prostaglandin and leukotriene biosynthesis through suppression of 5-lipoxygenase or prostaglandin synthetase. However, it is established that neither ginger nor its constituents produce the gastrointestinal adverse effects that are usually produced by the conventional non steroidal antiinflammatory drugs as a result of prostaglandin inhibition (Konturek et al., 2005). In fact, the cytoprotective and gastric anti-ulcer effect of ginger have been showed experimentally in early studies in rats (Yamahara et al., 1988; Wu et al., 1990). Recently, data provides evidence for the potential ulcer-preventive ability of phenolics in ginger aqueous extract and addresses the probable mode of action through the inhibition of gastric $\mathrm{H}^{+}, \mathrm{K}^{+}$-ATPase and Helicobacter pylori growth (Siddaraju et al., 2007; Nanjundaiah et al., 2009).

Thus, ginger and many of its chemical constituents have been shown, in numerous experimental and clinical studies, to be useful in combating several health disturbances, providing evidences to explain the actions of folk medicines in terms of conventional biochemistry and pharmacology.

\section{Myracrodruon urundeuva Allemão, Anacardiaceae (aroeira-do-sertão)}

Myracrodruon urundeuva Allemão, Anacardiaceae, a medicinal plant known as 'aroeira-dosertão', is a prominent species in the regional Caatinga vegetation and very popular in the Northeastern of Brazil. Locally, it has been used in folk medicine as an antiinflammatory agent in the treatment of gynaecological and gastrointestinal problems, as well as in skin and mucous lesions cicatrization process. Decoction, infusion in water, syrup and intimate soaps are some of the manners of popular use (Matos et al., 2001; Monteiro et al., 2006).

Chemical fractionation studies revealed that the M. urundeuva ethyl acetate extract has two main fractions, one rich in chalcones and the other one rich in tannins. Chalcones are biosynthetic precursors of flavonoids and together to other biogenetically related compounds are collectively called flavonoids. Tannins can be classified as hydrolysable and condensed and, as flavonoids, they are polyphenols, which act as astringents that shrink tissues and contract structural proteins in the skin and mucosa. It has been shown that both fractions are involved with the pharmacological activity of the plant (Viana et al., 1997; 2003).

Dimeric chalcones isolated from bark showed analgesic effects and anti-inflammatory activity in several experimental models of inflammation (Viana et al., 2003; Araico et al., 2007). Many of chalcones derivatives have been found to be also antioxidant (Miranda et 
al., 2000), molluscicidal (Adewunmi et al., 1987) and antimicrobial (Nielsen et al., 2004). In addition to these pharmacological actions, in recent study carried out by researchers from our laboratory (Nobre-Junior et al., 2009), a chalcone-enriched fraction isolated from the stem bark of $M$. urundeuva presented neuroprotective action on 6-hydroxydopamine (6-OHDA)-induced neuronal cell death, in rat mesencephalic cells. The authors suggested that the anti-oxidative properties of chalcone-enriched fraction could partly explain its neuroprotective effect. In this sense, the fraction was able to completely reverse the drastic increase in thiobarbituric acid reactive substances formation induced by 6-OHDA, besides decreasing the 6-OHDA-induced nitrite formation.

The tannin fraction from M. urundeuva was also found to possess analgesic and anti-inflammatory pharmacological effects in several experimental tests conducted by collaborators from our laboratory (Viana et al., 1997). The antinociceptive effect was not reversed by the opioid antagonist naloxone, pointing to the noninvolvement of the opioid system in the antinociception, and suggesting a peripheral action. Also, similarly to aspirin, the response in the formalin test 2nd phase was more sensitive to inhibition by tannin fraction, suggesting that it acts through the inhibition of prostaglandin synthesis. In addition, an antioedematogenic effect in rat paw oedema induced by both carrageenan and dextran models was also observed in the cited study. Subsequently (Souza et al., 2007), antiinflammatory and antiulcer effects from tannin-enriched fraction were credited to its antioxidant action, known to be present in polyphenols, including tannins.

As referred above, in Northeast Brazil $M$. urundeuva has been commonly used as antiinflammatory agent for the treatment of gastrointestinal diseases. In this sense, Rodrigues et al. (2002) showed the effects of M. urundeuva, in the form of enemas prepared from the stem bark, on several morphologic and morphometric parameters after acetic acid-induced colitis in rats. Results evidenced that animals treated with $M$. urundeuva showed complete epithelial tissue regeneration, while in the controls chronic inflammatory exudate persisted and tissue regeneration occurred through fibrosis. It is possible that the antiinflammatory properties of tannin fraction isolated from the plant stem barkthese are, at least in part, responsible for the decrease in oedema and inflammatory exudate and also for the complete epithelial regeneration.

In addition, a recent study evaluated the effect of a topical herbal gel from Lippia sidoides and Myracrodruon urundeuva (5\%) (aroeira-do-sertao) in experimental periodontal disease in rats (Botelho et al., 2007). The authors showed that the combined gel treatment preserved alveolar bone resorption and demonstrated anti-inflammatory and antibacterial activities in experimental periodontitis. In a more recent report, Crivelaro de Menezes et al. (2010) evaluated the influence of $M$. urundeuva aqueous extracts on $S$. mutans counts and dental enamel micro-hardness of rats submitted to a cariogenic challenge. The authors concluded that the extract tested had a significant effect on $S$. mutans in oral biofilm of the rats, decreasing $S$. mutans accumulation and enamel demineralization. In fact, $M$. urundeuva is considered a hardwood, very dense, elastic and resistant to microorganisms and termites and, therefore, studies were conducted in order to evaluate its antimicrobial activity against bacteria and fungi that attack plants, including woods. In this sense, a lectin isolated from heartwood was showed to inhibit Gram-negative and Gram-positive bacteria and was more effective than antifungal Cercobin (a recognized systemic fungicide) in growth inhibition of phytopathogenic fungi (Sá et al., 2009), corroborating the antimicrobial potential of this species.

Taken together, scientific studies about pharmacological properties from M. urundeuva validate its extensive traditional use in the treatment of gynecological conditions, skin and mucous lesions and gastrointestinal disturbances, as well as evidence further therapeutic potential from this plant and their constituents.

\section{Final Considerations}

Although an expressive number of medicinal plant species from the Caatinga region is known and used in folk medicine, detailed studies of their pharmacological and biological activity are still needed. On the other hand, the native and introduced species or their active constituents revised in the present study demonstrated potential targets for future use as a dietary supplement or as a drug therapy. In this sense, we suggest that these species and compounds be examined for a wider range of pharmacological activities. Therefore, the Caatinga region should be of high conservation priority and thus research efforts should be directed to the sustainable management of those species integrated with vegetation management in disturbed areas.

\section{References}

Adewunmi CO, Ogungbamila FO, Oluwadiya JO 1987. Molluscicidal activities of some synthetic chalcones. Planta Med 53: 110-112.

Aeschbach R, Loliger J, Scott BC, Murcia A, Butler J, Halliwell B, Aruoma OI 1994. Antioxidant actions of thymol, carvacrol, 6-gingerol, zingerone and hydroxytyrosol. Food Chem Toxicol 32: 31-36.

Aguiar MJN, De S Neto NC, Braga CC, Brito JIB, Silva EDV, Silva MAV, Costa1 CAR, Lima JB 2001. Zoneamento 
pedoclimático para a cultura do cajueiro (Anacardium occidentale L.) na Região Nordeste do Brasil e no norte de Minas Gerais. Rev Bras Agromet 9: 557-563.

Agra MF, França PF, Barbosa-Filho JM 2007. Synopsis of the plants known as medicinal and poisonous in Northeast of Brazil. Rev Bras Farmacogn 17: 114-140.

Albuquerque UP, Andrade LHC 2002. Uso de recursos vegetais da Caatinga: o caso do agreste do Estado de Pernambuco (Nordeste do Brasil). Interciencia 7: 336-345.

Albuquerque UP, Andrade LHC, Silva ACO 2005. Use of plant resources in a seasonal dry Forest (Northeastern Brazil). Acta Bot Bras 19: 27-38.

Albuquerque UP, Medeiros PM, Almeida ALS, Monteiro JM, Lins Neto EMF, Melo JG, Santos JP 2007. Medicinal plants of the caatinga (semi-arid) vegetation of $\mathrm{NE}$ Brazil: A quantitative approach. J Ethnopharmacol 114: 325-354.

Ali BH, Blunden G, Tanira MO, Nemmar A 2008. Some phytochemical, pharmacological and toxicological properties of $Z$. officinale (Zingiber officinale Roscoe): a review of recent research. Food Chem Toxicol 46: 409-420.

Almeida CFCBR, Albuquerque UP 2002. Uso e conservação de plantas e animais medicinais no estado de Pernambuco (Nordeste do Brasil): um estudo de caso. Interciencia 27: 276-285.

Almeida CFCBR, Amorim ELC, Albuquerque UP, Maia MBS 2006. Medicinal plants popularly used in the Xingo region-a semi-arid location in northeastern Brazil. $J$ Ethnobiol Ethnomed 23: 2-15.

Almeida ER, Guedes MC, Albuquerque JFC, Xavier H 2006 a. Hypoglycemic effect of Bauhinia cheilandra in rats. Fitoterapia 77: 276-278.

Almeida ER, Rafael KRO, Couto GBL, Ishigami ABM 2009. Anxiolytic and anticonvulsant effects on mice of flavonoids, linalool, and $\alpha$-tocopherol presents in the extract of leaves of Cissus sicyoides L. (Vitaceae). J Biomed Biotechnol 2009: 1-6. Verificar referência

Almeida ER, Soares RPF, Lucena FFR, Oliveira JRG, Albuquerque JFC, Couto GBL 2006b. Central antinociceptive effects of Cissus sicyoides on mice. Pharm Biol 44: 304-308.

Almeida RN, Navarro DS, Barbosa-Filho JM 2001. Plants with central analgesic activity. Phytomedicine 8: 310-322.

Altman RD, Marcussen KC 2001. Effects of a ginger extract on knee pain in patients with osteoarthritis. Arthritis Rheum 44: 2531-2538.

Amaral JF, Silva MI, Neto MR, Neto PF, Moura BA, de Melo CT, de Araújo FL, de Sousa DP, de Vasconcelos PF, de Vasconcelos SM, de Sousa FC 2007. Antinociceptive effect of the monoterpene R-(+)-limonene in mice. Biol Pharm Bull 30: 1217-1220.

Araico A, Terencio MC, Alcaraz MJ, Dominguez JN, León C, Ferrándiz ML 2007. Evaluation of the antiinflammatory and analgesic activity of Me-UCH9, a dual cyclooxygenase-2/5 lipoxygenase inhibitor. Life Sci 80: 2108-2117.

Arrieta J, Benitez J, Flores E, Castillo C, Navarrete A 2003. Purification of gastroprotective triterpenoids from the stem bark of Amphipterygium adstringens; role of prostaglandins, sulfhydryls, nitric oxide and capsaicinsensitive neurons. Planta Med 69: 905-909.

Banskota AH, Tezuka Y, Adnyana IK, Xiong Q, Hase K, Tran KQ, Tanaka K, Saiki I, Kadota S 2000. Hepatoprotective effect of Combretum quadrangulare and its constituents. Biol Pharm Bull 23: 456-460.

Barbosa-Filho JM, Vasconcelos THC, Alencar AA, Batista LM, Oliveira RAG, Guedes DN, Falcão HS, Moura MD, Diniz MFFM, Modesto-Filho J 2005. Plants and their active constituents from South, Central, and North America with hypoglycemic activity. Rev Bras Farmacogn 15: 392-413.

Barros LM, Pimentel CRM, Correa MPF, Mesquita ALM 1993. Recomendações técnicas para a cultura do cajueiroanão-precoce. Fortaleza: Embrapa-CNPAT, p. 65.

Beltrame FL, Pessini GL, Doro DL, Dias Filho BP, Bazotte RB, Cortez DAG 2002. Evaluation of the antidiabetic and antibacterial activity of Cissus sicyoides. Braz Arch Biol Techn 45: 21-25.

Beltrame FL, Sartoretto JL, Bazotte RB, Cuman RN, Cortez DAG 2001. Estudo Fitoquímico e avaliação do potencial antidiabético do Cissus sicyoides L. (Vitaceae). Quim Nova 24: 783-785.

Bode A 2003. Ginger is an effective inhibitor of HCT116 human colorectal carcinoma in vivo. Frontiers in Cancer Prevention Research Conference, Phoenix, United States.

Bolsoni AKH, Demoner C, Vulpi TS, Silva AG 2008. The use of plant species as hypoglycemiant phytotherapics. Natureza on line 6: 19-23.

Botelho MA, Rao VS, Carvalho CBM, Bezerra-Filho JG, Fonseca SGC, Vale ML, Montenegro D, Cunha F, Ribeiro RA, Brito GA 2007. Lippia sidoides and Myracrodruon urundeuva gel prevents alveolar bone resorption in experimental periodontitis in rats. $J$ Ethnopharmacol 113: 471-478.

Braga R 1976. Plantas do Nordeste especialmente do Ceará, 3ed., Imprensa Oficial, Fortaleza, p. 219.

Brash AR 1999. Lipoxygenase: occurrence, functions, catalysis and acquisition of substrate. J Biol Chem 274: 2367923682.

Bravo B, Sauvain M 1999. Bioactive phenolic glycosides from Amburana cearensis. Phytochemistry 50: 71-74.

Cabral SCMC, Agra MF 1998. Etnomedicina e farmacobotânica das Capparaceae da caatinga paraibana, Brasil. Rev Bras Farm 79: 2-6.

Cano JH, Volpato G 2004. Herbal mixtures in the traditional medicine of Eastern Cuba. J Ethnopharmacol 90: 293316.

Canuto KM, Silveira ER 2006. Chemical constituents of trunk 
bark of Amburana cearensis (A.C. Smith). Quim Nova 29: $1-3$

Castillo-Juárez I, Rivero-Cruz F, Celis H, Romero I 2007. AntiHelicobacter pylori activity of anacardic acids from Amphipterygium adstringens. $J$ Ethnopharmacol 114 : 72-77.

Carvajal D, Casaco A, Arruzazabala L, Gonzalez R, Sierra P, Fajardo M, Timor C, Robaina C, Fuentes V 1983. Pharmacological screening of plant detections commonly used in cuban folk medicine. J Ethnopharmacol 33: 21 24.

Chemexcil 1992. Selected Medicinal Plants of India. Basic Chemicals, Pharmaceutical and Cosmetic Export Promotion Council, Bombay, India, p. 205-207.

Chen JC, Huang LJ, Wu SL, Kuo SC, Ho TY, Hsiang CY 2007. Z. officinale and its bioactive component inhibit enterotoxigenic Escherichia coli heat labile enterotoxins-induced diarrhea in mice. J Agric Food Chem 55: 8390-8397.

Chung WY, Jung YJ Surh YJ, Lee SS, Park KK 2001. Antioxidative and antitumor promoting effects of [6]paradol and its homologs. Mutat Res 496: 199-206.

Coppey LJ, Gellett JS, Davidson EP, Yorek MA 2003. Preventing superoxide formation in epineurial arterioles of the sciatic nerve from diabetic rats restores endotheliumdependent vasodilation. Free Radic Res 37: 33-40.

Corrêa Junior C, Ming LC, Scheffer MC 1994. Cultivo de plantas medicinais, condimentares e aromáticas. 2. ed. Jaboticabal: FUNEP, p. 162.

Correia MP 1984. Dicionário de plantas úteis do Brasil e das exóticas cultivadas, Imprensa Nacional, Ministério da Agricultura, Rio de Janeiro: Brasil, p. 266-267.

Costa-Lotufo LV, Jimenez PC, Wilke DV, Leal LKAM, Cunha GMA Silveira ER, Canuto KM, Viana GSB, Moraes MEA, Moraes MO, Pessoa C 2003. Antiproliferative effects of several compounds isolated from Amburana cearensis A. C. Smith. Z Naturforsch C 58: 675-680.

Costa-Neto EM, Oliveira, MVM 2000. The use of medicinal plants in the country of Tanquinho, State of Bahia, northeastern Brazil. Rev Bras Plant Med 2: 1-8.

Crivelaro de Menezes TE, Botazzo Delbem AC, Lourenção Brighenti F, Cláudia Okamoto A, Gaetti-Jardim E Jr. Protective efficacy of Psidium cattleianum and Myracrodruon urundeuva aqueous extracts against caries development in rats. Pharm Biol 48: 300-305.

Cui L, Miao J, Furuya T, Fan Q, Li X, Rathod PK, Su XZ, Cui L 2008. Histone acetyltransferase inhibitor anacardic acid causes changes in global gene expression during in vitro Plasmodium falciparum development. Eukaryotic Cell 7: 1200-1210.

Da Cunha AM, Menon S, Menon R, Couto AG, Bürger C, Biavatti MW 2010. Hypoglycemic activity of dried extracts of Bauhinia forficata Link. Phytomedicine 17: $37-41$.

Damasceno DC, Volpato GT, Calderon IMP, Rudge MVC 2004.
Effect of Bauhinia forficata extract in diabetic pregnant rats: maternal repercussions. Phytomedicine 11: 196201.

Delgobo CL, Gorin PAJ, Jones C, Iacomini M 1998. Gum heteropolysaccharide and free reducing monoand oligosaccharide of Anadenanthera colubrina. Phytochemistry 47: 1207-1214.

De Lima SG, Feitosa CM, Cito AMGL, Moita Neto JM, Lopes JAD, Leite AS, Brito MC, Dantas SMM, Melo Cavalcante AAC 2008. Effects of immature cashew nutshell liquid (Anacardium occidentale) against oxidative damage in Saccharomyces cerevisiae and inhibition of acetylcholinesterase activity. Genet Mol Res 7: 806818.

De Meyer N, Haemers A, Mishra L, Pandey HK, Pieters LAC, Berghe DAV, Vlietinck AJ 1991. 4'-Hydroxy-3methoxyflavones with potent antipicornavirus activity. J Med Chem 34: 736-746.

De Sousa DP, Gonçalves JCR, Quintans-Júnior L, Cruz JS, Araújo DA, de Almeida RN 2006. Study of anticonvulsant effect of citronellol, a monoterpene alcohol, in rodents. Neurosci Lett 401: 231-235.

De Sousa E, Zanatta L, Seifriz I, Creczynski-Pasa TB, Pizzolatti MG, Szpoganicz B, Silva FR 2004. Hypoglycemic effect and antioxidant potential of kaempferol-3,7-O(alpha)-dirhamnoside from Bauhinia forficata leaves. $J$ Nat Prod 67: 829-832.

Dey L, Attele AS, Yuan CS 2002. Alternative therapies for type 2 diabetes. Altern Med Rev 7: 45-58.

Di Carlo G, Di Carlo G, Autore G, Izzo AA, Maiolino P, Mascolo N, Viola P, Diurno MV, Capasso F 1993. Inhibition of intestinal motility and secretion by flavonoids in mice and rats: structure activity relationships. J Pharm Pharmacol 45: 1054-1059.

Duke JA, Ayensu ES 1985. Medicinal Plants of China. Medicinal Plants of the World. Vol. 1. Algonac, MI: Reference Publications, Inc.: 362.

Elisabetsky E, Carrera MP, Texeira KMC, Muller AH, Moura BAS 1988. Atividade anticonvulsivante do Cipó puca (Cissus sicyoides). X Simpósio de Plantas Medicinais do Brasil. São Paulo, Brasil.

Fang J, Seki T, Maeda H 2009. Therapeutic strategies by modulating oxygen stress in cancer and inflammation. Adv Drug Deliv Rev 61: 290-302.

Ferreira MP, Nishijima CM, Seito LN, Dokkedal AL, LopesFerreira M, Di Stasi LC, Vilegas W, Hiruma-Lima CA 2008. Gastroprotective effect of Cissus sicyoides (Vitaceae): involvement of microcirculation, endogenous sulfhydryls and nitric oxide. $J$ Ethnopharmacol 117: 170-174.

Ferri MG 1980. Vegetação brasileira. Belo Horizonte: Itatiaia Ltda/EDUSP, São Paulo.

Flynn DL, Rafferty MF, Boctor AM 1986. Inhibition of human neutrophil 5-lipoxygenase activity by gingerdione, shogaol, capsaicin and related pungent compounds. 
Prostaglandins Leukot Med 24: 195-198.

Franca F, Lago EL, Marsden PD 1996. Plants used in the treatment of leishmanial ulcers due to Leishmania (Viannia) braziliensis in an endemic area of Bahia, Brazil. Rev Soc Bras Med Trop 29: 229-232.

Galvez J, Zarzuelo A, Crespo ME, Lorente MD, Ocete MA, Jimenez J 1993. Antidiarrhoeic activity of Euphorbia hirta extract and isolation of an active flavonoid constituent. Planta Med 59: 333-336.

García MD, Quílez AM, Sáenz MT, Martínez-Domínguez ME, de la Puerta R 2000. Anti-inflammatory activity of Agave intermixta Trel. and Cissus sicyoides L., species used in the Caribbean traditional medicine. J Ethnopharmacol 71: 395-400.

García X, Cartes-Heredia L, Lorenzana-Jimenez M, Gijón E 1997. Vasoconstrictor effect of Cissus sicyoides on guinea-pig aortic rings. Gen Pharmacol 29: 457-462.

Geiger JL 2005. The essential oil of ginger, Zingiber officinale, and anaesthesia. Internat J Aromather 15: 7-14.

Gonzalez-Mujica F, Motta AN, Marquez AH, Capote-Zulueta J 2003. Effects of Bauhinia megalandra aqueous leaf extract on intestinal glucose absorption and uptake by enterocyte brush border membrane vesicles. Fitoterapia 74: 84-90.

Grant KL, Lutz RB 2000. Alternative therapies: ginger. Am J Health Syst Pharm 57: 945-947.

Grontved A, Brask T, Kambskard J, Hentzer E 1988. Ginger root against seasickness. A controlled trial on the open sea. Acta Otolaryngol (Stockh) 105: 45-49.

Gupta AK, Vidyapati TJ, Chauhan JS 1980. Chemical examination of the stem of Bauhinia divaricata. Planta Med 38: 174-176.

Gutierrez-Lugo MT, Deschamps JD, Holman TR, Suarez E, Timmermann BN 2004. Lipoxygenase inhibition by anadanthoflavone, a new flavonoid from the aerial parts of Anadenanthera colubrina. Planta Med 70: 263-265.

Han SB, Lee CW, Jeon YJ, Hong ND, Yoo ID, Yang KH, Kim HM 1999. The inhibitory effect of polysaccharides isolated from Phellinus linteus on tumor growth and metastasis. Immunopharmacology 41: 157-164.

Havsteen B 1983. Flavonoids, a class of natural products of high pharmacological potency. Biochem Pharmacol 32: 1141-1148.

Holtmann S, Clarke AH, Scherer H, Hohn M 1989. The antimotion sickness mechanism of ginger. A comparative study with placebo and dimenhydrinate. Acta Otolaryngol (Stockh) 108: 168-174.

Huang QR, Iwamoto M, Aoki S, Tanaka N, Tajima K, Yamahara J, Takaishi Y, Yoshida M, Tomimatsu T, Tamai Y 1991. Anti-5-hydroxytryptamine 3 effect of galanolactone, diterpenoid isolated from ginger. Chem Pharm Bull 39: 397-399.

Hueck K 1972. As florestas da América do Sul: ecologia, composição e importância econômica. São Paulo/ Brasília: Polígono/Ed. da Universidade de Brasília.
Jorge AP, Horst H, Sousa E, Pizzolatti MG, Silva FRMB 2004. Insulinomimetic effects of kaempferitrin on glycaemia and on ${ }^{14} \mathrm{C}$-glucose uptake in rat soleus muscle. Chem Biol Interact 149: 89-96.

Juliane C 1929. Ação hipoglicemiante da unha-de-vaca. Rev Med Pharm Chim Phys 2: 165-169.

Juliane C 1931. Ação hipoglicemiante da Bauhinia forficata Link, novos estudos experimentais. Rev Sud Amer Endocrinol Imunol Quimioter 14: 326-334.

Kamtchouing P, Sokeng SD, Moundipa PF, Watcho P, Jatsa HB, Lontsi D 1998. Protective role of Anacardium occidentale extract against streptozotocin-induced diabetes in rats. J Ethnopharmacol 62: 95-99.

Keum YS, Kim J, Lee KH, Park KK, Surh YJ, Lee JM, Lee SS, Yoon JH, Joo SY, Cha IH, Yook JI 2002. Induction of apoptosis and caspase- 3 activation by chemopreventive [6]-paradol and structurally related compounds in KB cells. Cancer Lett 177: 41-47.

Khalil NM, Pepato MT, Brunetti IL 2008. Free radicals scavenging profile and myeloperoxidase inhibition of extracts from antidiabetic plants: Bauhinia forficata and Cissus sicyoides. Biol Res 41: 165-171.

Kiuchi F, Shibuya M, Sankawa U 1982. Inhibitors of prostaglandin biosynthesis from ginger. Chem Pharm Bull 30: 754-757.

Kiuchi F, Iwakami S, Shibuya M, Hanaoka F, Sankawa U 1992. Inhibition of prostaglandin and leukotriene biosynthesis by gingerols and diarylheptanoids. Chem Pharm Bull 40: 387-391.

Konan NA, Bacchi EM 2007. Antiulcerogenic effect and acute toxicity of a hydroethanolic extract from the cashew (Anacardium occidentale L.) leaves. J Ethnopharmacol 112: 237-242.

Konturek SJ, Konturek PC, Brzozowski T 2005. Prostaglandins and ulcer healing. J Physiol Pharmacol 56: 5-31.

Kozubek A, Zarnowski R, Stasiuk M, Gubernator J 2001. Natural amphiphilic phenols as biofungicides. Cell Mol Biol Lett 6: 351-355.

Kubo I, Ochi M, Vieira PC 1993. Antitumor agents from the cashew (Anacardium occidentale) apple juice. J Agric Food Chem 41: 1012-1015.

Kubo I, Ha TJ, Tsujimoto K, Tocoli FE, Green IR 2008. Evaluation of lipoxygenase inhibitory activity of anacardic acids. Z Naturforsch C 63: 539-546.

Kubo I, Nihei K, Tsujimoto K 2003. Antibacterial action of anacardic acids against methicillin resistant Staphylococcus aureus (MRSA). J Agric Food Chem 51: 7624-7628.

Langner E, Greifenberg S, Gruenwald J 1998. Ginger: history and use. Adv Ther 15: 25-44.

Leal LKAM, Canuto KM, Costa KCS, Nobre-Júnior HV, Vasconcelos SM, Silveira ER, Ferreira MVP, Fontenele JB, Andrade GM, Viana GSB 2009. Effects of amburoside A and isokaempferide, polyphenols from Amburana cearensis on rodent inflammatory processes 
and myeloperoxidase activity in human neutrophils. Basic Clin Pharmacol Toxicol 104: 198-205.

Leal LKAM, Costa MF, Pitombeira M, Barroso VM, Silveira ER, Canuto KM, Viana GSB 2006. Mechanisms underlying the relaxation induced by isokaempferide from Amburana cearensis in the guinea-pig isolated trachea. Life Sci 79: 98-104.

Leal LKAM, Fonseca FN, Pereira FA, Canuto KM, Felipe CFB, Fontenele JB, Pitombeira MV, Silveira ER, Viana GSB 2008. Protective effects of amburoside A, apPhenol glucoside from Amburana cearensis, against CCl4induced hepatotoxicity in rats. Planta Med 74: $497-$ 502.

Leal LKAM, Nechio M, Silveira ER, Canuto KM, Fontenele JB, Ribeiro RA, Viana GSB 2003. Anti-inflammatory and smooth muscle relaxant activities of the hydroalcoholic extract and chemical constituents from Amburana cearensis A. C. Smith. Phytother Res 17: 335-340.

Leal LKAM, Nobre Júnior HV, Cunha GMA, Moraes MO, Pessoa C, Oliveira RA, Silveira ER, Canuto KM, Viana GSB 2005. Amburoside A, a glucoside from Amburana cearensis, protects mesencephalic cells against 6-hydroxydopamine-induced neurotoxicity. Neurosci Lett 388: 86-90.

Lee E, Park KK, Lee JM, Chun KS, Kang JY, Lee SS, Surh YJ 1998. Suppression of mouse skin tumor promotion and induction of apoptosis in HL-60 cells by Alpinia oxyphylla Miquel (Zingiberaceae). Carcinogenesis 19. 1377-1381.

Lee E, Surh YJ 1998. Induction of apoptosis in HL-60 cells by pungent vanilloids, [6]-gingerol and [6]-paradol. Cancer Lett 134: 163-168.

Liang MH 1992. From america: cookbook medicine or food for thought: practice guidelines development in USA. Ann Rheum Dis 51: 1257-1258.

Lim H, Kim MK, LimY, Cho YH, Lee CH 2006. Inhibition of cell-cycle progression in HeLa cell sby HY52, an ovelcyclin-dependent kinase inhibitor isolated from Bauhinia forficata. Cancer Lett 233: 89-97.

Lino CS, Diógenes JPL, Pereira BA, Faria RAPG, Andrade NETO M, Alves RS, Queiroz MGR, Sousa FCF, Viana GSB 2004. Antidiabetic activity of Bauhinia forficata extracts in alloxan-diabetic rats. Biol Pharm Bull 27: 125-127.

Lopes VS, Dantas TN, Maciel MAM, Assis ZMS, Galdino VS, Araújo IS, Camacho CL, Chacon DP 2003. Clinical evaluation of Anacardium occidentale. Rev Bras Cienc Farm 39: 235-235.

Lorenzi H, Matos AFJ 2002. Plantas medicinais do Brasil. São Paulo: Instituto Plantarum.

Luiz-Ferreira A, Cola-Miranda M, Barbastefano V, HirumaLima CA, Vilegas W, Souza Brito AR 2008. Should Anacardium humile St. Hil be used as an antiulcer agent? A scientific approach to the traditional knowledge. Fitoterapia 79: 207-209.
Lutterodt GD, Ismail A, Basheer RH, Mohd Baharuddin H 1999. Antimicrobial effects of Psidium guajava extract as one mechanism of its antidiarrhoeal action. Malay $J$ Med Sci 6: 17-20.

Macedo M, Ferreira AR 2004. Plantas hipoglicemiantes utilizadas por comunidades tradicionais na Bacia do Alto Paraguai e Vale do Guaporé, Mato Grosso - Brasil. Rev Bras Farmacogn 14: 45-47.

Mahady GB, Pendland SL, Stoia A, Hamill FA, Fabricant D, Dietz BM, Chadwick LR 2005. In vitro susceptibility of Helicobacter pylori to botanical extracts used traditionally for the treatment of gastrointestinal disorders. Phytother Res 19: 988-991.

Mahady GB, Pendland SL, Yun GS, Lu ZZ, Stoia A 2003. Ginger (Zingiber officinale Roscoe) and the gingerols inhibit the growth of $\mathrm{Cag} \mathrm{A}^{+}$strains of Helicobacter pylori. Anticancer Res 23: 3699-3702.

Maia GN 2004. Caatinga: árvores e arbustos e suas utilidades. São Paulo: Leitura \& Arte.

Martin-Gallan P, Carrascosa A, Gussinye M, Domínguez C 2003. Biomarkers of diabetes associated oxidative stress and antioxidant status in young diabetic patients with or without subclinical complications. Free Radic Biol Med 34: 1563-1574.

Masuda Y, Kikuzaki H, Hisamoto M, Nakatani N 2004. Antioxidant properties of gingerol related compounds from ginger. Biofactors 21: 293-296.

Matos FJA, Viana GSB, Bandeira MAM 2001. Guia fitoterápico, 2. ed. Fortaleza

Melo-Cavalcante AA, Rübensam G, Erdtmann B, Brendel M, Henriques JAP 2005. Cashew (Anacardium occidentale) apple juice lowers mutagenicity of aflatoxin B1 in $S$. thyphimurium. Genet Mol Biol 28: 328-333.

Melo-Cavalcante AA, Rubensam G, Picada JN, Gomes da SE, Fonseca Moreira JC, Henriques JAP 2003. Mutagenicity, antioxidant potential, and antimutagenic activity against hydrogen peroxide of cashew (Anacardium occidentale) apple juice and cajuina. Environ Mol Mutagen 41: 360369.

Miranda CL, Stevens JF, Ivanov V, Mccall M, Frei B, Deinzer ML, Buhler DR 2000. Antioxidant and prooxidant actions of prenylated and nonprenylated chalcones and flavonones in vitro. J Agric Food Chem 48: 3876-3884.

Miranda D, Pereira L, Sirsat SM, Antarkar DS, Vaidya AB 1993. In vitro action of Dadima (Punica granatum Linn.) against microorganisms involved in human gastrointestinal infections-isolation and identification of tannins. J Res Ayur Siddha 14: 154-164.

Miyake ET, Akisue G, Akisue MK 1986. Pharmacognostic characterization of Pata-de-Vaca (Bauhinia forficata). Rev Bras Farmacogn 1: 56-68.

Monteiro JM, de Albuquerque UP, Lins-Neto EM, de Araujo EL, de Amorim EL 2006. Use patterns and knowledge of medicinal species among two rural communities in Brazil's semi-arid northeastern region. JEthnopharmacol 
105: 173-186.

Morais SM, Dantas JDP, Silva ARA, Magalhães EF 2005. Plantas medicinais usadas pelos índios Tapebas do Ceará. Rev Bras Farmacogn 15: 169-177.

Morais TC, Pintoa NB, Carvalho KMMB, Rios JB, Ricardo NMPS, Trevisan MTS, Rao VS, Santos FA 2010. Protective effect of anacardic acids from cashew (Anacardium occidentale) on ethanol-induced gastric damage in mice. Chem Biol Interact 183: 264-269.

Moretão MP, Buchi DF, Gorin PAJ, Iacomini M, Oliveira MBM 2003. Effect of an acidic heteropolysaccharide (ARAGAL) from the gum of Anadenanthera colubrina (Angico branco) on peritoneal macrophage functions. Immunol Lett 89: 175-185.

Moretão MP, Zampronio AR, Gorin PA, Iacomini M, Oliveira MB 2004. Induction of secretory and tumoricidal activities in peritoneal macrophages activated by an acidic heteropolysaccharide (ARAGAL) from the gum of Anadenanthera colubrina (Angico branco). Immunol Lett 93: 189-197.

Mori T, Nishikawa Y, Takata Y, Kashuichi N, Ishihara N 2001. Effect of insulina leaf extraction on development of diabetes - Comparison between normal, streptozotocininduced diabetic rats and hereditary diabetic mice. $J$ Japanese Soc Nutr Food Sci 54: 197-203.

Mota MLR, Thomas G, Barbosa-Filho JM 1985. Antiinflammatory actions of tannins isolated from the bark of Anacardium occidentale. J Ethnopharmacol 13: 289300 .

Nadkarni AK 1976. Indian Materia Medica. 3 ed. Mumbai: Popular Press Ltda.

Nanjundaiah SM, Annaiah HN, M Dharmesh S 2009. Gastroprotective effect of ginger rhizome (Zingiber officinale) extract: role of gallic acid and cinnamic acid in $\mathrm{H}^{+}, \mathrm{K}^{+}$-ATPase $/ H$. pylori inhibition and antioxidative mechanism. Evid Based Complement Alternat Med 1: 1-13.

Nielsen SF, Boesen T, Larsen M, Schonning K, Kromann H 2004. Antibacterial chalcones-bioisosteric replacement of the 4'-hydroxy group. Bioorg Med Chem 12: $3047-$ 3054.

Nobre-Júnior HV, Oliveira RA, Maia FD, Nogueira MA, de Moraes MO, Bandeira MA, Andrade GM, Viana GS 2009. Neuroprotective effects of chalcones from Myracrodruon urundeuva on 6-hydroxydopamineinduced cytotoxicity in rat mesencephalic cells. Neurochem Res 34: 1066-1075.

Nostro A, Cellini L, Di Bartolomeo S, Cannatelli MA, Di Campli E, Procopio F, Grande R, Marzio L, Alonzo V 2006. Effects of combining extracts (from propolis or Zingiber officinale) with clarithromycin on Helicobacter pylori. Phytother Res 20: 187-190.

Nurtjahja-Tjendraputra E, Ammit AJ, Roufogalis BD, Tran VH, Duke CC 2003. Effective anti-platelet and COX-1 enzyme inhibitors from pungent constituents of ginger.
Thromb Res 111: 259-265.

Ojewole JA 2004. Potentiation of the antiinflammatory effect of Anacardium occidentale (L.) stem-bark aqueous extract by grapefruit juice. Methods Find Exp Clin Pharmacol 26: 183-188.

Olajide OA, Aderogba MA, Adedapo AD, Makinde JM 2004. Effects of Anacardium occidentale stem bark extract on in vivo inflammatory models. J Ethnopharmacol 95: 139-42.

Oliveira CZ, Maiorano VA, Marcussi S, Sant'ana CD, Januário AH, Lourenço MV, Sampaio SV, França SC, Pereira PS, Soares AM 2005. Anticoagulant and antifibrinogenolytic properties of the aqueous extract from Bauhinia forficata against snake venoms $J$ Ethnopharmacol 98: 213-216. Verificar referência

Oliveira F, Saito ML 1987. Alguns vegetais brasileiros empregados no tratamento da diabetes. Rev Bras Farmacogn 4: 170-190.

Oliveira RRB, Góis RMO, Siqueira RS, Almeida JRGS, Lima JT, Nunes XP, Oliveira VR, Siqueira JS, Quintans-Júnior LJ 2009. Antinociceptive effect of the ethanolic extract of Amburana cearensis (Allemão) A.C. Sm., Fabaceae, in rodents. Rev Bras Farmacogn 19: 672-676.

Ooi VEC, Liu F 2000. Immunomodulation and anti-cancer activity of polysaccharide-protein complexes. Curr Med Chem 7: 715-729.

Otshudi AL, Foriers A, Vercruysse A, Van Zeebroek A, Lauwers S 2000. In vitro antimicrobial activity of six medicinal plants traditionally used for the treatment of dysentery and diarrhoea in Democratic Republic of Congo (DRC). Phytomedicine 7: 167-172.

Ozgoli G, Goli M, Simbar M 2009. Effects of ginger capsules on pregnancy, nausea, and vomiting. J Altern Complement Med 15: 243-246.

Palharin LHC, Figueiredo Neto E, Camargo Lopes MP, Bosquê GG 2008. Estudo sobre gengibre (Zengiber officinale) na medicina popular. www.revista.inf.br/agro14/notas/ AnoVII- $\neg$ Edic14-nota01.pdf, accessed Nov 2010.

Park EJ, Pizzuto JM 2002. Botanicals in cancer chemoprevention. Cancer Metastasis Rev 21: 231255.

Pepato MT, Baviera AM, Vendramini RC, Perez MPMS, Kettelhut IC, Brunetti IL 2003. Cissus sicyoides (princess vine) in the long-term treatment of streptozotocin-diabetic rats. Biotechnol Appl Biochem 37: 15-20.

Pereira JM, Severino RP, Vieira PC, Fernandes JB, Silva MF, Zottis A, Andricopulo AD, Oliva G, Corrêa AG 2008. Anacardic acid derivatives as inhibitors of glyceraldehyde-3-phosphate dehydrogenase from Trypanosoma cruzi. Bioorg Med Chem 19: 8889-8895.

Pereira RC, Oliveira MTR, Lemos GCS 2004. Plantas utilizadas como medicinais no município de Campos de Goytacazes - RJ. Rev Bras Farmacogn 14: 37-40.

Qureshi S, Shah AH, Tariq M, Ageel AM 1989. Studies on 
herbal aphrodisiacs used in Arab system of medicine. Am J Chin Med 17: 57-63.

Ribeiro MCP, Ávila DS, Schneider CYM, Hermes FS, Furian AF, Oliveira MS, Rubin MA, Lehmann M, Krieglstein J, Mello CF 2005. $\alpha$-Tocopherol protects against pentylenetetrazol- and methylmalonate-induced convulsions. Epilepsy Res 66: 185-194.

Rodd R 2002. Snuff synergy: preparation, use, and pharmacology of yopo and Bonisteriopsis caopi among the Piaroa of southern Venezuela. J Psychoactive Drugs 34: 273279.

Rodrigues LV, Ferreira FV, Regadas FSP, Matos D, Viana GSB 2002. Morphologic and morphometric analyses of acetic acid-induced colitis in rats after treatment with enemas from Myracrodruon urundeuva Fr. All. (Aroeira do Sertão). Phytother Res 16: 267-272.

Sadik CD, Sies H, Schewe T 2003. Inhibition of 15-lipoxygenase by flavonoids: structure-activity relation and mode of action. Biochem Pharmacol 65: 773-781.

Saeidnia S, Gohari AR, Ito M, Kiuchi F, Honda G 2005. Bioactive constituents from Dracocephalum subcapitatum (O. Kuntze) Lipsky. Z Naturforsch C 60: 22-24.

Saenz MT, Garcia MD, Quilez A, Ahumada MC 2000. Cytotoxic activity of Agave intermixtya L. (Agavaceae) and Cissus sicyoides L. (Vitaceae). Phytother Res 14: 552-554.

Santos HB, Modesto-Filho J, Diniz MFFM, Vasconcelos THC, Pereira FSB, Ramalho JA, Dantas JG, Santos EB 2008. Evaluation of the hypoglycemic effect of Cissus sicyoides in phase II clinical trials. Rev Bras Farmacogn 18: 70-76.

Sá RA, Gomes FS, Napoleão TH, Santos NDL, Melo CML, Gusmão NB, Coelho LCBB, Paiva PMG, Bieber LW 2009. Antibacterial and antifungal activities of Myracrodruon urundeuva heartwood. Wood Sci Techno 43: 85-95.

Sharma H, Clark C 1998. Contemporary Ayurveda. Churchill Livingstone, London, pp. 100-101.

Siddaraju MN, Dharmesh SM, Siddaraju MN, Dharmesh $\mathrm{SM}$ 2007. Inhibition of gastric $\mathrm{H}^{+}, \mathrm{K}^{+}$-ATPase and Helicobacter pylori growth by phenolic antioxidants of Zingiber officinale. Mol Nutr Food Res 51: 324-332.

Silva ACO, Albuquerque UP 2005. Woody medicinal plants of the caatinga in the state of Pernambuco (Northeast Brazil). Acta Bot Bras 19: 17-26.

Silva MI, de Aquino Neto MR, Teixeira Neto PF, Moura BA, do Amaral JF, de Sousa DP, Vasconcelos SM, de Sousa FC 2007. Central nervous system activity of acute administration of isopulegol in mice. Pharmacol Biochem Behav 88:141-147.

Silva MIG, Gondim APS, Nunes IFS, Sousa FCF 2006. Utilização de fitoterápicos nas unidades básicas de atenção à saúde da família no município de Maracanaú (CE). Rev Bras Farmacogn 16: 455-462.

Silva MI, Moura BA, Neto MR, Tomé Ada R, Rocha NF, de Carvalho AM, Macêdo DS, Vasconcelos SM, de Sousa
DP, Viana GS, de Sousa FC 2009a. Gastroprotective activity of isopulegol on experimentally induced gastric lesions in mice: investigation of possible mechanisms of action. Naunyn Schmiedebergs Arch Pharmacol 380: 233-245.

Silva MI, Silva MA, de Aquino Neto MR, Moura BA, de Sousa HL, de Lavor EP, de Vasconcelos PF, Macêdo DS, de Sousa DP, Vasconcelos SM, de Sousa FC 2009b. Effects of isopulegol on pentylenetetrazol-induced convulsions in mice: possible involvement of GABAergic system and antioxidant activity. Fitoterapia 80: 506-513.

Sontakke S, Thawani V, Naik MS 2003. Ginger as an antiemetic in nausea and vomiting induced by chemotherapy: a randomized, cross-over, double blind study. Indian $J$ Pharmacol 35: 32-36.

Sousa FCF, Melo CT, Monteiro AP, Lima VT, Gutierrez SJ, Pereira BA, Barbosa-Filho JM, Vasconcelos SM, Fonteles MF, Viana GS 2004a. Antianxiety and antidepressant effects of riparin III from Aniba riparia (Nees) Mez (Lauraceae) in mice. Pharmacol Biochem Behav 78: 27-33.

Sousa FCF, Pereira BA, Lima VTM, Lacerda CDG, Melo CTV, Barbosa-Filho JM, Vasconcelos SMM, Viana GSB 2005. Central nervous system activity of yangambin from Ocotea duckei Vattimo (Lauraceae) in mice. Phytother Res 19: 282-286.

Souza SM, Aquino LC, Milach AC Jr, Bandeira MA, Nobre ME, Viana G 2007. Antiinflammatory and antiulcer properties of tannins from Myracrodruon urundeuva Allemao (Anacardiaceae) in rodents. Phytother Res 21: 220-225.

Steele VE, Holmes CA, Hawk ET, Kopelovich L, Lubet RA, Crowell JA, Sigman CC, Kelloff GJ 1999. Lipoxygenase inhibitors as potential cancer chemopreventives. Cancer Epidemmiol Biomarkers Prev 8: 467-483.

Stewart JJ, Wood MJ, Wood CD, Mims ME 1991. Effects of ginger on motion sickness susceptibility and gastric function. Pharmacology 42: 111-120.

Sung B, Pandey MK, Ahn KS, Yi T, Chaturvedi MM, Liu M, Aggarwal BB 2008. Anacardic acid (6-nonadecyl salicylic acid), an inhibitor of histone acetyltransferase, suppresses expression of nuclear factor-kappaBregulated gene products involved in cell survival, proliferation, invasion, and inflammation through inhibition of the inhibitory subunit of nuclear factorkappaB alpha kinase, leading to potentiation of apoptosis. Blood 111: 4880-4891.

Toledo MCF, Reyes FGR, Iaderoza M, Fancis FJ, Draetta IS 1983. Anthocyanins from anil trepador (Cissus sicyoides, Linn.), J Food Sci 48: 1368-1369.

Toyomizu M, Okamoto K, Ishibashi T, Chen Z, Nakatsu T 2000. Uncoupling effect of anacardic acids from cashew nut shell oil on oxidative phosphorylation of rat liver mitochondria. Life Sci 66: 229-234.

Trevisan MTS, Pfundstein B, Haubner R, Wurtele G, 
Spiegelhalder B, Bartsch H, Owen RW 2006. Characterization of alkyl phenols in cashew (Anacardium occidentale) products and assay of their antioxidant capacity. Food Chem Toxicol 44: 188197.

Tzeng YM, Chen K, Rao YK, Lee MJ 2009. Kaempferitrin activates the insulin signaling pathway and stimulates secretion of adiponectin in 3T3-L1 adipocytes. Eur $J$ Pharmacol 607: 27-34.

Vanderlinde FA, Landim HF, Costa EA, Galdino PM, Maciel MAM, Anjos GC, Malvar DC, Côrtes WS, Rocha FF 2009. Evaluation of the antinociceptive and antiinflammatory effects of the acetone extract from Anacardium occidentale L. Rev Bras Cienc Farm 45: 437-442.

Viana GS, Bandeira MA, Matos FJ 2003. Analgesic and antiinflammatory effects of chalcones isolated from Myracrodruon urundeuva Allemao. Phytomedicine 10: 189-195.

Viana GS, Bandeira MA, Moura LC, Souza-Filho MVP, Matos FJA, Ribeiro RA 1997. Analgesic and antiinflammatory effects of the tannin fraction from Myracrodruon urundeuva Fr All. Phytother Res 11: 118-122.

Viana GS, Medeiros AC, Lacerda AM, Leal LK, Vale TG, Matos FJ 2004. Hypoglycemic and anti-lipemic effects of the aqueous extract from Cissus sicyoides. BMC Pharmacol 8: 4-9.

Volpato GT, Damasceno DC, Calderon IMP, Rudge MVC 2002. Revisão de plantas brasileiras com comprovado efeito hipoglicemiante no controle do Diabetes mellitus. Rev Bras Plant Med 4: 35-45.

Volpato GT, Damascenoa DC, Rudgea MVC, Padovani CR, Calderon IMP 2008. Effect of Bauhinia forficata aqueous extract on the maternal-fetal outcome and oxidative stress biomarkers of streptozotocin-induced diabetic rats. J Ethnopharmacol 116: 131-137.

Yamahara J, Mochizuki M, Rong HQ, Matsuda H, Fujimura H 1988. The anti-ulcer effect in rats of ginger constituents. J Ethnopharmacol 23: 299-304.

Yamahara J, Rong HQ, Iwamoto M, Kobayashi G, Matsuda H, Fujimura H 1989. Active components of ginger exhibiting antiserotinergic action. Phytother Res 3: 7071.

Yamamoto N, Kabuto H, Matsumoto S, Ogawa N, Yokoi I 2002. $\alpha$-Tocopheryl-L-ascorbate-2-O-phosphate diester, a hydroxyl radical scavenger, prevents the occurrence of epileptic foci in a rat model of post-traumatic epilepsy. Pathophysiology 8: 205-214.

Yoshikawa M, Hatakeyama S, Chatani N, Nishino Y, Yamahara J 1993. Qualitative and quantitative analysis of bioactive principles in Zingiberis Rhizoma by means of high performance liquid chromatography and gas liquid chromatography. On the evaluation of Zingiberis Rhizoma and chemical change of constituents during Zingiberis Rhizoma processing. Yakugaku Zasshi 113: 307-315.

You KM, Jong H-G, Kim HP 1999a. Inhibition of cyclooxygenase/lipoxygenase from human platelets by polyhydroxylated/methoxylated flavonoids isolated from medicinal plants. Arch Pharm Res 22: 18-24.

You KM, Jong H-G, Kim HP 1999b. Inhibition of cyclooxygenase/lipoxygenase from human platelets by polyhydroxylated/methoxylated flavonoids. Biochem Pharmacol 65: 773-781.

Wang Y, Hamburger M, Gueho J, Hostettmann K 1989. Antimicrobial flavonoids from Psiadia trinervia and their methylated and acetylated derivatives. Phytochemistry 28: 2323-2327.

Wang T, Zhang JC, Chen Y, Huang F, Yang MS, Xiao PG 2007. Comparison of antioxidative and antitumor activities of six flavonoids from Epimedium koreanum. Zhongguo Zhong Yao Za Zhi 32: 715-718.

Weng CJ, Wu CF, Huang HW, Ho CT, Yen GC 2010. Antiinvasion effects of 6-shogaol and 6-gingerol, two active components in ginger, on human hepatocarcinoma cells. Mol Nutr Food Res 54: 1618-1627.

Wu H, Ye D, Bai Y, Zhao Y 1990. Effect of dry ginger and roasted ginger on experimental gastric ulcers in rats. Zhongguo Zhong Yao Za Zhi 15: 278-280, 317-318.

\section{*Correspondence}

\section{Francisca C. F. Sousa}

Departamento de Fisiologia e Farmacologia, Faculdade de Medicina, Universidade Federal do Ceará

Rua Cel. Nunes de Melo 1127, 60430-270, Fortaleza-CE, Brazil

clea@ufc.br

Tel. +558533668337

Fax: +558533668333 